\title{
Urban Competitiveness and Public Housing
}

\author{
Sen Zhang ${ }^{1}$ \\ ${ }^{1}$ College of Public Administration, Tianjin University of Commerce, Tianjin, China \\ Correspondence: Sen Zhang, College of Public Administration, Tianjin University of Commerce, Beichen \\ district 300134, Tianjin, China. Tel: 86-159-0022-2886. E-mail: iefocus2010@hotmail.com
}

\author{
Received: February 10, 2013 Accepted: March 21, 2013 Online Published: April 27, 2013 \\ doi:10.5539/ass.v9n5p94 \\ URL: http://dx.doi.org/10.5539/ass.v9n5p94
}

\begin{abstract}
The purpose of this study is to link the security housing with urban competitiveness improvement, this is the new trend of the current housing reform field. It is proposed that under new development situation, we should change the traditional concept of housing security, establish a modern concept of housing security, combine public housing with enhancing the competitiveness of city, through the establishment of various policy systems, make use of market mechanisms to resolve the housing problem by way of development. Do a good job in public housing, can contribute to the competitiveness of the city, thus achieve mutual promotion between the two. We must establish the modern concept of housing security, swift from the traditional focus on welfare to pay attention to social benefits, combine the development of public housing with urban competitiveness.
\end{abstract}

Keywords: urban competitiveness, public housing, housing policy

Urban competitiveness is the new issue of urban management rising in foreign countries in recent years, and the study of urban competitiveness put forward higher requirements for city managers in terms of knowledge level and ability. Since the 1980s, researches on urban competition and urban competitiveness have been attracting close attention of foreign scholars and policy-makers. There are quite a number of research institutions in the United States specializing in the study of "urban competitiveness "; the United Kingdom issued a series of "white papers" on the issue of urban competitiveness in the 1990s; in recent years, OECD has also made relevant reports on urban competitiveness, especially the impact of "new economy", "new industry" on the the city competitiveness. Domestic scholars also began the city competitive researches in the late 20th century. Past studies focused on the analysis of industrial economics, with few discussion and probe into the role played by urban infrastructure represented by public housing in the city competitiveness.

\section{Analysis of the Key Elements of Urban Competitiveness}

Urban competitiveness is the vitality of the city development. The competitiveness was first proposed in business management. The World Economic Forum (WEF) put forward the concept of competitiveness in Report on Competitiveness Capacity for the first time. Enterprise competitiveness refers to "At present and in the future in their respective environment, the capacity and opportunity that enterprises own to carry out the design, production and sale of goods and services and opportunities with more attractive price and quality, than their domestic and foreign competitors." Up to today, the concept of competitiveness has been widely used in various fields, especially in the urban competitiveness.

The economist Professor Iain Begg attempted to divide factors influencing urban economic behavior into different competitive factors. As it can be seen from Figure 1, the advantage of Professor Iain Begg's urban competitiveness model lies in the finding that the ultimate goal of city operation is to improve the standard living of urban residents. However, the competitive advantage of a city should not only reflected in the economic operation of the city, should also be reflected in the social and environmental aspects, because the city itself is not a closed system, you must also consider the impact of external factors on the city system. 


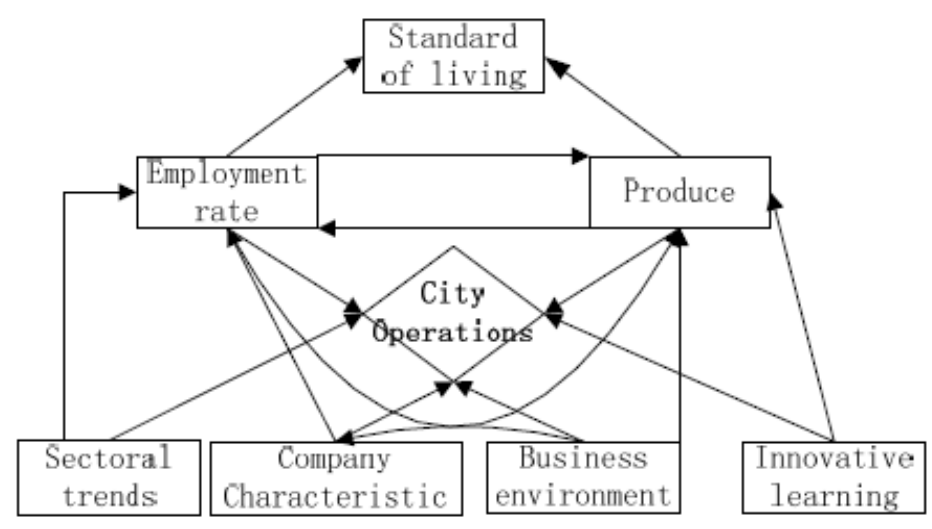

Figure 1. Iain Begg's urban competitiveness model

It is not difficult to find, urban competitiveness is determined not only by the city's industry, competitive environment nurturing and coordination of the competitive process are also the key to success. The urban government should nurture or improve the "hardware" and "software" environment of competition, in order to promote the improvement of the city's competitiveness. Public housing plays a vital role in improving the standard of living of urban residents. Below we explore the relationship of city competitiveness and public housing.

\section{The Promoting Relations between Public Housing and Urban Competitiveness}

Urban Competitiveness is the comprehensive reflection of the ability of a city, but not just the city's comprehensive strength. Specifically, urban competitiveness refers to many aspects of a city's social and economic structures, values, cultural, institutional and policy together, the ability of cities to integrate all endowments within the area, so as to achieve the optimal configuration of various resources, the final performance of city competitiveness is the ability to create wealth in the city. The carrier of city competitiveness is the investment cost, market opportunities, the degree of internationalization, government management and service, social security and social order, ecological environment and quality of life, culture, health care, sports, education environment, public transport and communications infrastructure construction as well as the quality of the citizens and human resource costs. The connotation of city competitiveness is constituted by the three major aspects of competitiveness: basic competitiveness, environmental competitiveness and core competitiveness.

Among the components of urban competitiveness, the basic competitiveness of the city is the key. The basic competitiveness of city is the urban basic structure system featured in the physical form, primarily consists of a variety of facilities and quality that the city can make use of, including transportation system, communication system, energy and power system, housing stock, culture, public health, scientific and educational institutions and facilities. City basic competitiveness is the carrier of city competitiveness, to determine the efficiency of the economic, social and cultural activities in the city, and the basic competitiveness is generated by the corresponding infrastructure, determining the wealth creation capacity of the city.

Urban competitive is more concerned about how the labor forces (human capital), land and capital as the three elements of production, to maximize the benefits in the city configuration, Housing, as an important factor in the reproduction of human resources, directly determines the cost of living in a city, ultimately affects the competitiveness of the city.

City housing constitutes the real estate market and the security housing market, especially the establishment of city's affordable housing system has a direct impact on the city labor costs, with the development of various cities, the traditional mode of affordable housing is gradually broken, replaced by the formation of a brand-new housing security system - the public housing system. In the public housing system, the government and the social forces become the subjects of equality, jointly act on the public housing system, then form a brand new public housing system with multiparty participating in: the government, the construction unit, banking and financial institutions, security objects. As can be seen from Iain Begg's urban competitiveness model, the living cost in the city has a crucial impact on the competitiveness of the city, and the maturity of a city public housing system directly determines the competitiveness of the city. Therefore, the only way to enhance the competitiveness of the city is to do a good job in the public housing system. 


\section{The Restrictions of the Public Housing System to City Competitiveness}

While each city's public housing system has made certain achievements in practice, it is far from the objective requirements of urban competitiveness further play. The following problems existing in the specific practice restrict the maturity of the public housing system, and also restrict the city competitive play.

\subsection{Only Concerned Starts in, Ignore the "Result-Oriented"}

Development of affordable housing, we must not only focus on the number of start, but also focus on reasonable layout of affordable housing, the scale and spatial layout of new-built houses should have a strict scientific proof, and strive to avoid the low-income population inhabited; it is better to change some stock houses into public housing through the government operation than build new security houses. There are a lot of advantages to purchase and store from stock property. The practice of various States also confirmed this approach minimizes the impact on the real estate industry, can also promote the development of urban competitiveness.

\subsection{Enhance Security Objects Accurately, to Meet the Long-Term and Short-Term Requirements}

Major cities, especially cities in the rapid urbanization process, the introduction of talent and outside practitioners has become an important part of resident population, and every year a lot of new household population become an important driving force for urban development. But this also caused a certain level of complexity and diversification of housing security objects. In modern big cities, there are two types of urgent housing needs: one is long-term housing needs of low-income families, and the other is short-term housing needs of outside practitioners. Different from security objects with long-term housing difficulties in the past, the stage living difficulties of those newly increased population are more highlighted. Housing security system should continue to adapt to the new changes in situation, and to explore new mechanisms to meet the long-term social and stage these two types of housing difficulties. To resolve the housing difficulties of different groups, we should provide housing security specifically, so as to improve the efficiency and scientificity of the housing security, thus contributing to the city's labor competitiveness, and ultimately to promote the competitiveness of the city.

\subsection{Emphasize the Role of Government Policy, to Provide Public Housing through "Market Concept"}

The government should be the coordinator and designer of the system of public housing construction, rather than the direct provider of public housing. We should emphasize the "market concept" in the provision of public housing; encourage the real estate companies and non-profit organizations to develop non-profit social housing by providing tax and financial means, and provide efficient and low-cost housing security for individuals in the entire city.

\section{Build a Public Housing System to Promote the Play of City Competitiveness}

The public housing has a crucial role in the urban competitiveness, we should follow the "citizen-centered", "results-oriented" and "market philosophy" three principles, to build the city's public housing system, so as to attract more talents go into the city, reducing the cost of living in the city, and ultimately promote city competitiveness.

\subsection{Follow the Principle of "Citizen-Centered", Improve the "Public Housing" Policy System}

"Citizen-centered" is also known as "People-oriented", mainly refers to treat citizens as the starting point and ultimate goal of all public organizations work. The city's public housing construction is the same to improve the living standards of the citizens, to put civil right of residence into practice as the ultimate goal. Many cities have initially formed the housing guarantee system with a combination of "rent, sale, subsidy", mating public rental housing, price-capped housing, low-cost housing, shanty rebuilt housing, affordable housing together. Types of public housing have up to five, it is very rich in terms of type. However, only the pursuit of quantity is not enough, it is need to match with scientific policy instruments.

In the new construction of public housing, the transformation of the existing stock of the security houses should be mined and played. Through a variety of channels of reconstruction, acquisition, leasing agents, we raise the public housing availability. Speed up to put the existing stock of public housing into the public housing market to meet the housing needs of the majority of low-and middle-income groups. Many cities already have a large base number of public housing stock due to the long-term security housing construction, if they can effectively use the inventory of the existing public housing, it will be able to greatly ease the current status quo of social housing difficulties, in order to attract more talent to work in the city, thus contributing to enhance the competitiveness of the city. Seen from foreign experience, if the existing security housing can be rebuilt into public rental housing, it will greatly benefit low-income groups, such advantages: First, it is possible to avoid the formation of the new 
urban poor living in a compact community; second, followed by the ripe of around supporting facility also alleviate the economic burden of security objects; Finally, the cost of the existing security housing renovation is much lower than the cost of new security housing construction, it can play a greater social function with limited funds, thereby reducing the living cost in the city, promote the competitiveness of the city.

\subsection{Follow the Principle of "Results-Oriented", Establish the Public Housing System in Line with the Rapid Development of Urban Characteristics}

The advocacy of the principle of "results-oriented" is concerned about the achievement of the mission and goals of the organization, and public organizations should focus on the ultimate product and the actual social effects of the public goods provided. To adhere to the "results-oriented" in the field of public housing requires housing administration's management behavior should focus on the results, the merits of public housing performance should focus on the ultimate improvement of the competitiveness of the city rather than judge from the money invested and the number of affordable housing constructed. Therefore, we need to establish a housing security system corresponding to the rapid development of the city, in order to more effectively meet the housing needs of housing disadvantaged groups and to enhance the competitiveness of the city.

It should be clear that in a city with high population mobility, the influx of foreign population, the short-term difficulties of housing is much greater than the long-term difficulties. The government should focus on these short-term needs, and vigorously develop public rental housing, rather than construct a large number of price-capped housing with property rights. For the large number of public housing, it should adopt the rent not buy mode, implement deadline lease. So we can effectively use the security housing utilization, more targeted to meet the temporary housing needs, ultimately lowering the living cost of the entire city, to enhance the competitiveness of the city.

\subsection{Market Mechanisms}

The core of the "market concept" is to rediscover and take full advantage of the market value, embodied in the practice of public housing is the direction of the market-oriented reform of the public sector, contains encourage social capital entering, deregulation of government" retreat "and repositioning functions, and includes market actors and market mechanisms of public housing construction and allocation. The current plight of public housing construction is how to combine cheap and affordability of public housing, with the inevitable requirement of capital recyclability and capital growth of urban competitiveness improvement.

Public rental housing has the ability to cycle security funds, the government invests some capital, offers favorable conditions of land, taxes, utility charges, to support the development of a number of professional operators and institutions of public rental housing, makes use of market mechanisms to invest construction and management. Limit the lease term of public rental housing through legislation, the rent is slightly lower than the market price, to protect the interests of investors, to attract more social investment in the construction and operation of public rental housing. Through government partial money subsidy of housing tenant, tenants pay rental, investment and operating agencies obtain stable rental returns, a dynamic integration of government, investment institutions, tenants with housing difficulties is formed, promote the recycling of public housing funds, and ultimately help the housing difficulties groups with limited funds. Public housing, directly provided or subsidized by the government, is an important tool that governments adopted to respond to the failure of the housing market and to achieve the goal of housing policy.

In addition, the public housing with the common property can provide a steady stream of financial support for the construction of public housing, through the implementation of the "common property" mechanism. According to prior conventions in house sales contract, the housing security agencies and housing purchase family enjoy the property share according to the ration of investment. During house buyers' residence, the government transfers the right to use under its share; if the house buyer transfer the right to use a few years later in accordance with the regulations, buyers who, transfer the income together with housing security institutions in accordance with their respective equity share. Such regulations developed, can not only solve the problem of low-and middle-income family with inadequate capacity to pay housing fees, and ensure the current Government to protect the effective convergence and fairness of income distribution in future listing;

\subsection{Establish the Modern Concept of Public Housing, and Promote Common Development of Public Housing and Urban Competitiveness}

Taking great efforts to build public housing is not a simple to meet social stability, but to attract a lot of talent into the city so as to promote the rapid promotion of urban competitiveness. The massive construction of public rental housing and other public housing is primarily for the city's new immigration of the newborn skilled 
workers and professionals, they can help to improve the living environment of the community and increase social inclusion opportunities, and contribute to greatly enhance competitiveness of the City, thus do a good job in public housing can have a great role in promoting the competitiveness of the city. A city with perfect public housing can indirectly achieve accelerated urbanization, encourage foreign personnel to settle in, slow the rising speed of urban labor costs, expand domestic demand, promote industrial upgrading and structural adjustment. We must clearly recognize that the ultimate result of public housing is to maximize the social interests of the entire city, to accelerate the development of the city by public housing construction and renovation, to more effectively improve the efficiency in the use of land.

Therefore, the public housing construction and urban competitiveness development is highly interactive. We must establish the modern concept of housing security, the public housing policy has never been or should not be only concerned with the construction of public housing, such public housing policy is narrow-sensed and with no possibility of sustainable development. The height of the public housing policy must start from macro-strategic point of view, to improve urban competitiveness and urban economic and social development, in order to better play the competitiveness of the city, providing endless power for the upgrading of urban competitiveness.

\section{Conclusion}

Public housing has a crucial role for the urban competitiveness. With the rapid urbanization process, public housing policy has become increasingly demanding, traditional housing security concept form contradiction with the rapid development of city. This requires to change the traditional concept of housing security, to establish a modern concept of public housing, to combine public housing with city competitiveness improvement, through the establishment of public housing policy system, make use of market mechanisms to solve the housing problem. Just on the basis of good public housing, can we promote the development of urban competitiveness thus achieve mutual promotion between the two.

\section{References}

Begg, I. (1999). Cities and Competitiveness. Urban Studies, (36), 795-809. http://dx.doi.org/10.1080/0042098993222

Chen, J., Hao, Q. J., \& Stephens, M. (2010). Assessing Housing Affordability in Postreform China: A Case Study of Shanghai. Housing Studies, 25(6), 877-901. http://dx.doi.org/10.1080/02673037.2010.511153

Chen, T., \& Wang, W. (2006). Referring and Learning of Western Governments Reengineering for Our Modern Service-Oriented Government. Journal of Northwestern Polytechnical University, (5), 5-9.

Kearns, A., \& Paddison, R. (2000). New Challenges for Urban Governance. Urban Studies, (5), 5-7.

Kresl, P. K., \& Singh, B. (n. d.). Competitiveness and urban economy: Twenty-four large US metropolitan areas. Urban studies, 36(5-6), 1017-1027.

Lever, W. (1993). Competition Within the European Urban System. Urban Studies, (30), 935-948. http://dx.doi.org/10.1080/00420989320080871

People's Publishing House. (1995). Engels On the housing problem, the second edition of the Selected Works of Marx and Engels (Vol. 3). Beijing: People's Publishing House.

Potter et al. (Trans.). (1996). Competitive Advantage of Nations. Taiwan: World Image and Text Publishing Co.

Wang, W., Zhang, S., \& Gu, W. Z. (2013). Public Housing System Basing on Government Coordination Mechanism. Journal of Tianjin University, (1), 62-67.

Zhou, Z. R. (1996). Review and Outlook of China's Administrative System Reform. New Vision, (3), 41-44. 